\title{
Adenosine Stimulates Glycogenolysis in Mouse Cerebral Cortex: A Possible Coupling Mechanism Between Neuronal Activity and Energy Metabolism
}

\author{
Pierre J. Magistretti, Patrick R. Hof, and Jean-Luc Martin \\ Département de Pharmacologie, Centre Médical Universitaire, 1211 Geneva 4, Switzerland
}

Adenosine promotes a concentration-dependent hydrolysis of ${ }^{3} \mathbf{H}$ glycogen newly synthesized from ${ }^{3} \mathrm{H}$-glucose by mouse cerebral cortical slices. The $\mathrm{EC}_{50}$ for this effect is $7 \mu \mathrm{M}$. Theophylline antagonizes the glycogenolysis induced by adenosine with an $\mathrm{EC}_{50}$ of $80 \mu \mathrm{M}$. The rank-order of potencies of adenosine agonists is adenosine $5^{\prime}$-cyclopropyl-carboxamide $>2$-chloroadenosine $\gg N^{6}$-cyclohexyladenosine $=$ adenosine, suggesting that adenosine promotes glycogenolysis via receptors of the $A_{2}$ type. This contention is substantiated by the weak stereospecificity observed for the glycogenolytic action of $D$ - and L-(phenylisopropyl)-adenosine. The glycogenolysis elicited by adenosine at 10 and $100 \mu \mathrm{M}$ is inhibited by ouabain at $10 \mu \mathrm{M}$, a concentration of the cardiac glycoside not significantly affecting ${ }^{3} \mathrm{H}$-glycogen levels per se. Interestingly, the previously demonstrated glycogenolytic action of vasoactive intestinal peptide (Magistretti et al., 1981, 1984) and of norepinephrine (Quach et al., 1978) is also antagonized by ouabain.

These results demonstrate the existence of a metabolic action of adenosine, which is sensitive to ouabain and appears to be mediated by $A_{2}$ receptors. The concentrations at which adenosine promotes glycogenolysis are of the same order of magnitude as those reached extracellularly by the nucleoside during neuronal depolarization (Pull and McIlwain, 1972). This set of observations therefore supports the notion that adenosine plays a modulatory role in the coupling between neuronal activity and energy metabolism in the CNS.

In recent years, a large body of experimental evidence has been accumulated delineating a role for adenosine as mediator of intercellular communication in the CNS (for a recent review, see Snyder, 1985, and references therein). Such a view has emerged in part from the demonstration of a number of cellular actions of adenosine (Phillis and Wu, 1981; Snyder, 1985), which include the inhibition (at nanomolar concentrations) and stimulation (at micromolar concentrations) of adenylate cyclase (van Calker et al., 1978, 1979). The actions of adenosine are mediated by 2 types of receptors, $A_{1}$ and $A_{2}$, located on the extracellular surface of adenosine's target cells (van Calker et al., 1978, 1979; Bruns et al., 1980; for reviews, see Daly et al., 1981, and Daly, 1985). Furthermore, adenosine is released into the extracellular space from active neurons during electrically or chemically in-

\footnotetext{
Received Oct. 24, 1985; revised Feb. 18, 1986; accepted Mar. 18, 1986.

This work was supported by Fonds National Suisse de la Recherche Scientifique Grant 3.423-0.83 to P.J.M. We are grateful to Dr. Michel Schorderet for cAMP measurement and to Drs. J. Ferrero, J.-C. Maire, W. Pralong, and G. Van de Werve for providing useful references; we also wish to thank Ms. Sylvianne Bonnet for excellent secretarial assistance, Ms. Gisèle Gilliéron for technical help, and Mr. Fred Pillonel for graphical work.

Correspondence should be addressed to Pierre J. Magistretti, M.D., Ph.D., Département de Pharmacologie, Centre Médical Universitaire, Rue Michel Servet 1, 1211 Geneva 4, Switzerland.

Copyright (C) 1986 Society for Neuroscicnce $0270-6474 / 86 / 092558-05 \$ 02.00 / 0$
}

duced depolarizations (Schubert and Kreutzberg, 1974, 1975; Shimizu et al., 1970a), where concentrations of adenosine can reach 150-400 $\mu \mathrm{M}$ (Pull and McIlwain, 1972).

Certain neurotransmitters have been shown to display metabolic actions in the CNS, in addition to their effects on neuronal excitability (Magistretti and Morrison, 1985; Morrison and Magistretti, 1983). Thus, vasoactive intestinal peptide (VIP) (Magistretti et al., 1981) and the monoamines norepinephrine, histamine, and 5-HT (Quach et al., 1978, 1980, 1982) hydrolyze ${ }^{3} \mathrm{H}$-glycogen newly synthesized from ${ }^{3} \mathrm{H}$-glucose by mouse cerebral cortical slices. Interestingly, this energy-mobilizing process appears to occur, at least in part, in astrocytes (Magistretti et al., 1983), where glycogen is predominantly stored (Lajtha et al., 1981).

In the present set of investigations we have examined the effect of adenosine on glycogen levels in mouse cerebral cortical slices and have observed that (1) adenosine promotes glycogenolysis in the cerebral cortex, (2) this effect appears to be mediated by $A_{2}$ receptors, and (3) the glycogenolytic action of adenosine is antagonized by ouabain.

\section{Materials and Methods}

Swiss male albino mice (20-25 g) were used throughout this study; they were maintained in an alternating $12 \mathrm{hr}$ light/12 hr dark cycle and had free access to food and water.

Cerebral cortical slices were prepared as follows (Magistretti et al., 1981). Mice were decapitated and their brains rapidly removed. The cerebral cortex was then dissected on ice and immediately placed in a modified Krebs-Ringer bicarbonate buffer, pH 7.4 (KRG), containing (in $\mathrm{mM}$ concentration): $\mathrm{NaCl}, 120 ; \mathrm{KCl}, 3 ; \mathrm{CaCl}_{2}, 2.6 ; \mathrm{MgSO}_{4}, 0.67$; $\mathrm{KH}_{2} \mathrm{PO}_{4}, 1.2 ;$ glucose, $3 ; \mathrm{NaHCO}_{3}, 27.5$, previously gassed with $\mathrm{O}_{2}: \mathrm{CO}_{2}$ $(95: 5)$. The dissected cortices (usually 2 per experiment) were then placed on a McIlwain tissue chopper, their ventral aspect facing the chopping plate, and $250 \mu \mathrm{m}$ slices were prepared. The plate was then rotated by $90^{\circ}$, and the cortices were cut again. The slices were then resuspended in ice-cold KRG $\left(6 \mathrm{ml} /\right.$ cortex) and incubated during $15 \mathrm{~min}$ at $37^{\circ} \mathrm{C}$ under continuous gassing $\left(\mathrm{O}_{2}: \mathrm{CO}_{2}, 95: 5\right)$ and vigorous shaking. After replacing the medium, $270 \mu \mathrm{l}$ of the slice suspension was distributed into individual polypropylene test tubes, and $10 \mu \mathrm{l}^{3} \mathrm{H}$-glucose $(20 \mathrm{nmol})$ was added. After gassing with a stream of $\mathrm{O}_{2}: \mathrm{CO}_{2}(95: 5)$, the tubes were capped and incubated at $37^{\circ} \mathrm{C}$. Aftcr $30 \mathrm{~min}$, drugs $(20 \mu \mathrm{l})$ were added for $10 \mathrm{~min}$. Antagonists were added $3 \mathrm{~min}$ before the agonists. The tubes were then centrifuged, and the supernatant was removed and replaced with fresh KRG $(300 \mu l)$. The slice suspension was then sonicated for $5 \mathrm{sec}$, boiled for $10 \mathrm{~min}$, and centrifuged again.

${ }^{3} \mathrm{H}$-Glycogen was isolated from the supernatants by ethanol precipitation on filter paper as previously described (Magistretti et al., 1981; Quach et al., 1978; Solling and Esmann, 1975). Aliquots $(150 \mu \mathrm{l})$ of the deproteinized supernatants were pipetted on Whatman 31-ET filter paper disks ( $24 \mathrm{~mm}$ diameter) and immersed into an ice-cold $60 \%$ (vol vol) ethanol $/ 10 \%(\mathrm{wt} / \mathrm{vol})$ trichloracetic acid solution $(10 \mathrm{ml} / \mathrm{filter})$ for $10 \mathrm{~min}$. The filters were then placed into $66 \%$ ethanol solutions $(10 \mathrm{ml}$ filter) at room temperature for 6 successive $10 \mathrm{~min}$ periods. After a final $5 \mathrm{~min}$ in acetone, filters were dried, placed into scintillation counting vials, and counted for ${ }^{3} \mathrm{H}$ with an efficiency of $34 \%$. Using this isolation 


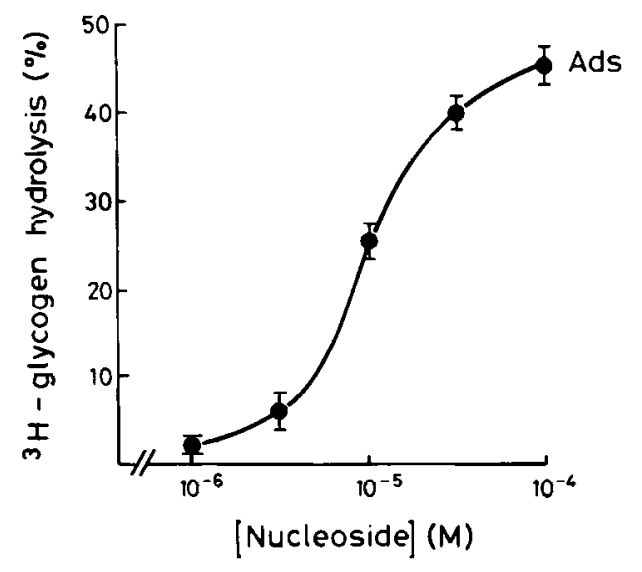

Figure 1. Concentration-response curve of the glycogenolytic effect of adenosine. Mouse cerebral cortical slices were incubated as described in Materials and Methods. Results are the means \pm SEM of 7 separate experiments and are expressed as percentages of basal ${ }^{3} \mathrm{H}$-glycogen levels hydrolyzed. Basal ${ }^{3} \mathrm{H}$-glycogen levels (cpm/mg protein): 18,124 \pm 1610 .

technique, contamination by glucose was $<0.5 \%$ and the glycogen recovery $>99 \%$ (Magistretti et al., 1984).

cAMP levels were determined as follows. Slices were incubated and treated in conditions identical to those used for the ${ }^{3} \mathrm{H}$-glycogenolysis assay, except for a $\mathrm{KCl}$ concentration of $5 \mathrm{~mm}$ in KRG. Aliquots of the supernatants $(10-100 \mu \mathrm{l})$ were lyophilized and resuspended in $20 \mu \mathrm{l}$ of Tris/EDTA $(0.05 \mathrm{M} / 4 \mathrm{mM})$ buffer. cAMP was then determined with the saturation assay method described by Brown et al. (1971). Experimental values were calculated by computer from a standard curve ranging from 0 to 16 pmol of cAMP.

Proteins were determined in the pellets as described by Lowry et al. (1951).

Adenosine 5'-cyclopropyl-carboxamide was a generous gift of Abbott Laboratories (North Chicago, IL), D- and L-N6-( $S$-phenylisopropyl)adenosine and adenosine were purchased from Boehringer Mannheim (Mannheim, FRG); theophylline, 2-chloroadenosine, and $\mathrm{N}^{6}$-cyclohexyladenosine from Sigma (St. Louis, MO), and ouabain (g-strophantin) from Mcrck (Darmstadt, FRG). 6- ${ }^{-} \mathrm{H}$-glucose $(0.5 \mathrm{Ci} / \mathrm{mmol})$ was purchased from Amersham International.

Statistical analysis was performed by the Student's $t$ test.

\section{Results}

Mouse cerebral cortical slices maintained in KRG at $37^{\circ} \mathrm{C}$ will synthesize ${ }^{3} \mathrm{H}$-glycogen from ${ }^{3} \mathrm{H}$-glucose in a time-dependent manner (Magistretti et al., 1981; Quach et al., 1978); within 30 min of incubation, stable levels of ${ }^{3} \mathrm{H}$-glycogen are reached, and the potential glycogenolytic effect of a given substance can be tested. As shown in Figure 1, adenosine promotes a concentration-dependent hydrolysis of the newly synthesized ${ }^{3} \mathrm{H}$-glycogen. The $\mathrm{EC}_{50}$ of adenosine in eliciting this action is $7 \mu \mathrm{M}$, with a maximal efficacy of $46 \%$ hydrolysis of basal ${ }^{3} \mathrm{H}$-glycogen levels (Fig. 1).

Figure 2 shows that the glycogenolytic effect of adenosine is antagonized in a concentration-dependent manner by theophylline $\left(\mathrm{EC}_{50}, 80 \mu \mathrm{M}\right)$, an antagonist of adenosine at the adenosine receptor level (Bruns et al., 1980; Sattin and Rall, 1970).

On the basis of the rank-order of potencies of adenosine agonists and of the nature of their cellular actions, 2 types of adenosine receptors have been described, denominated $A_{1}$ and $A_{2}$ (van Calker et al., 1978, 1979; Daly, 1985). As shown in Figure $3 A$, we observed that the glycogenolytic action of adenosine is mimicked by the metabolically stable analogs adenosine 5 '-cyclopropyl-carboxamide (ACC), 2-chloroadenosine (2ClA), and $N^{6}$-cyclohexyladenosine (CHA). Thus, ACC promotes ${ }^{3} \mathrm{H}$-glycogen hydrolysis with an $\mathrm{EC}_{50}$ of $150 \mathrm{~nm}$ and a maximal efficacy of $72 \%$, whereas these parameters are $600 \mathrm{nM}$ and $67 \%$ for $2 \mathrm{ClA}$ and $7 \mu \mathrm{M}$ and $66 \%$ for CHA (Fig. 3A). This pharmacological

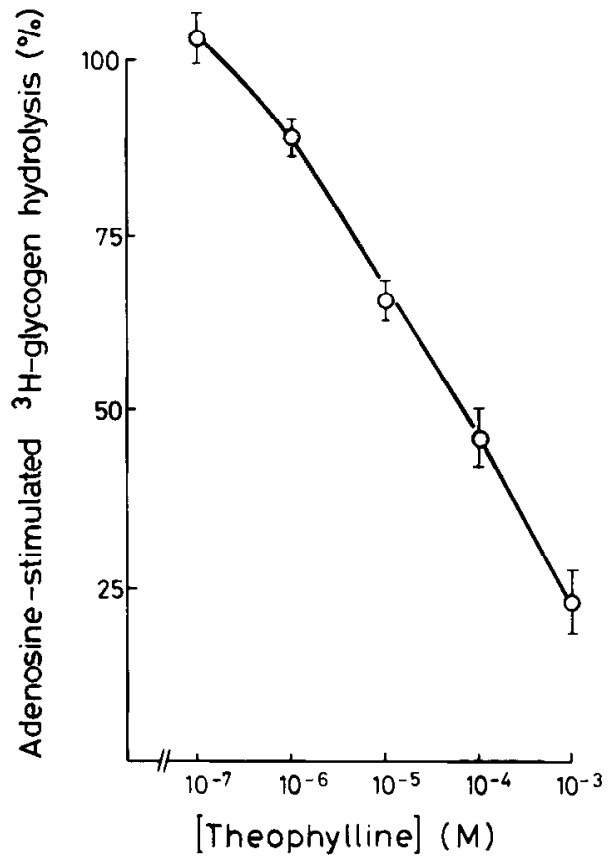

Figure 2. Concentration-response curve of the antagonism by theophylline of adenosine-stimulated ${ }^{3} \mathrm{H}$-glycogen hydrolysis. Mouse cerebral cortical slices were incubated as described in Materials and Methods. Results are the means \pm SEM of 3 separate experiments and are expressed as percentages of the maximal glycogenolytic effect of $100 \mu \mathrm{M}$ adenosine alone.

profile of potencies of $\mathrm{ACC}, 2 \mathrm{ClA}$, and $\mathrm{CHA}$ in eliciting glycogenolysis is suggestive of an adenosine effect mediated by the occupation of adenosine receptors of the $A_{2}$ type (Daly et al., 1981; Snyder, 1985). A finer tool to dissect the receptor type mediating adenosine's effects is provided by the use of the stereoisomers of phenylisopropyl-adenosine (PIA). Thus, at $A_{1}$ receptors L-PIA is approximately 70-100-fold more potent than D-PIA, while at $A_{2}$ receptors the stereospecificity is markedly reduced, with the L-isomer being only 3-5-fold more potent than the D-isomer (Daly et al., 1981; Smellie et al., 1979a). This latter profile of potencies was observed for the glycogenolytic effect of L-PIA and D-PIA (Fig. 3B), thus substantiating the notion that adenosine promotes glycogenolysis via $\mathrm{A}_{2}$ receptors.

We have subsequently examined the effect of the cardiac glycoside ouabain, an inhibitor of the $\mathrm{Na}^{+} / \mathrm{K}^{+}$-ATPase (Skou, 1965), on adenosine-induced glycogenolysis. As shown in Figure 4, ouabain, $10 \mu \mathrm{M}$, inhibited the hydrolysis of ${ }^{3} \mathrm{H}$-glycogen elicited by 10 and $100 \mu \mathrm{M}$ adenosine without significantly affecting ${ }^{3} \mathrm{H}-$ glycogen levels when tested alone. In contrast to its inhibitory action on adenosine-induced glycogenolysis, ouabain did not antagonize the stimulatory effect of adenosine on cAMP levels; in fact, ouabain, $100 \mu \mathrm{M}$, and adenosine, $100 \mu \mathrm{M}$, stimulated in a more than additive manner cAMP formation in mouse cerebral cortical slices incubated in conditions identical to those used for the ${ }^{3} \mathrm{H}$-glycogenolysis assay (Table 1 ).

As previously reported (Magistretti et al., 1981, 1984; Quach et al., 1978), the VIP and the monoamine norepinephrine (NE) promote a concentration-dependent ${ }^{3} \mathrm{H}$-glycogen hydrolysis in mouse cerebral cortex, with $\mathrm{EC}_{50}$ values of 26 and $500 \mathrm{nM}$, respectively. It therefore seemed of interest to examine the effect of ouabain on the glycogenolytic action of VIP and NE. As shown in Table $2,10 \mu \mathrm{M}$ ouabain inhibited almost completely the ${ }^{3} \mathrm{H}$-glycogen hydrolysis elicitcd by VIP, $0.5 \mu \mathrm{M}$, and NE, 1 $\mu \mathrm{M}$. 
Figure 3. Concentration-response curves of the glycogenolytic effect of ACC, 2ClA, CHA $(A)$ and of L-PIA and D-PIA $(B)$. Mouse cerebral cortical slices were incubated as described in Materials and Methods. Results are the means \pm SEM of 3-5 separate experiments. Results are expressed as percentages of basal ${ }^{3} \mathrm{H}-$ glycogen hydrolyzed. Basal ${ }^{3} \mathrm{H}$-glycogen levels (cpm/mg protein): 28,434 $\pm 1880(A)$ and $17,345 \pm 1787(B)$
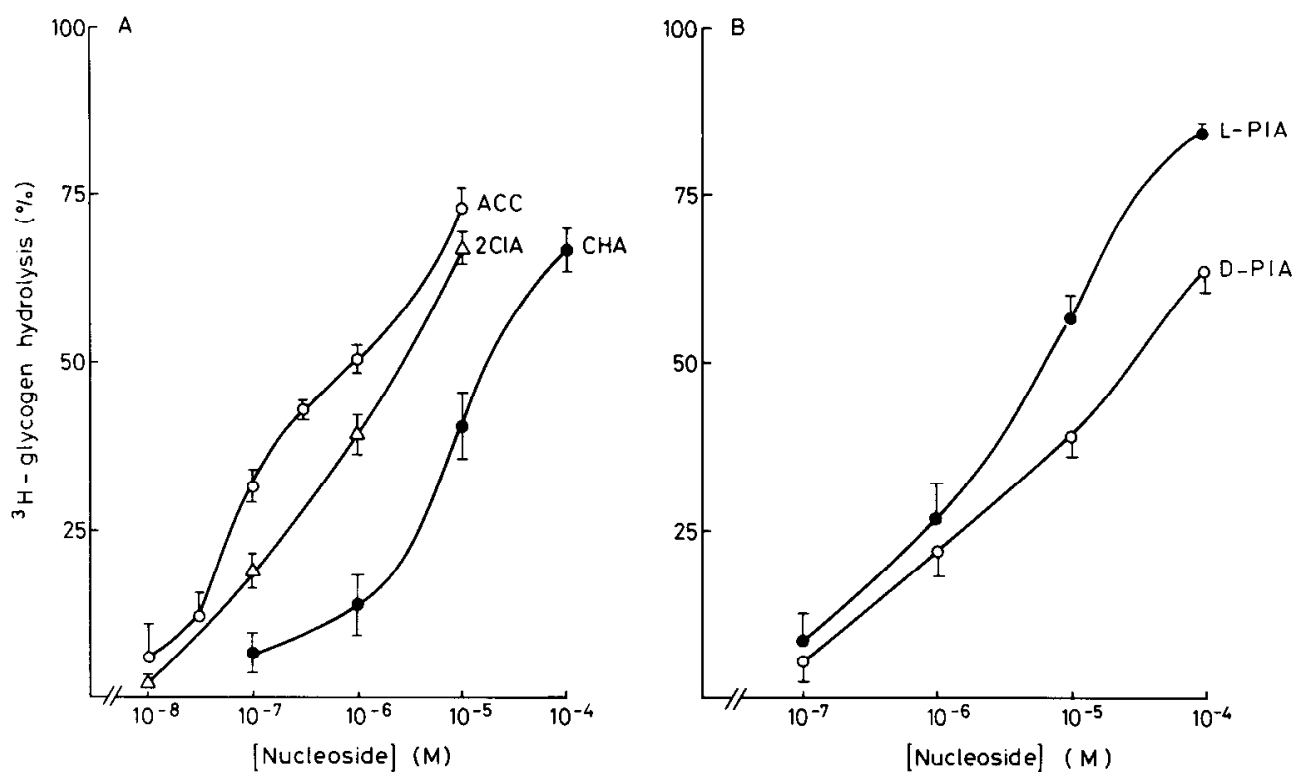

\section{Discussion}

In the series of experiments reported in this article we observed that adenosine promotes a concentration-dependent hydrolysis of ${ }^{3} \mathrm{H}$-glycogen newly synthesized from ${ }^{3} \mathrm{H}$-glucose by mouse cerebral cortical slices. This adenosine-mediated glycogenolysis is ouabain-sensitive.

The cellular actions of adenosine, mediated by the occupation of specific adenosine receptors, are antagonizcd by alkylxanthines such as theophylline (Bruns et al., 1983; Fredholm and Persson, 1982; Smellie et al., 1979b). Thus, the inhibitory effect of adenosine on the spontaneous and stimulus-evoked firing rate of neurons as well as the inhibition of the release of certain neurotransmitters is antagonized by theophylline (Kuroda,

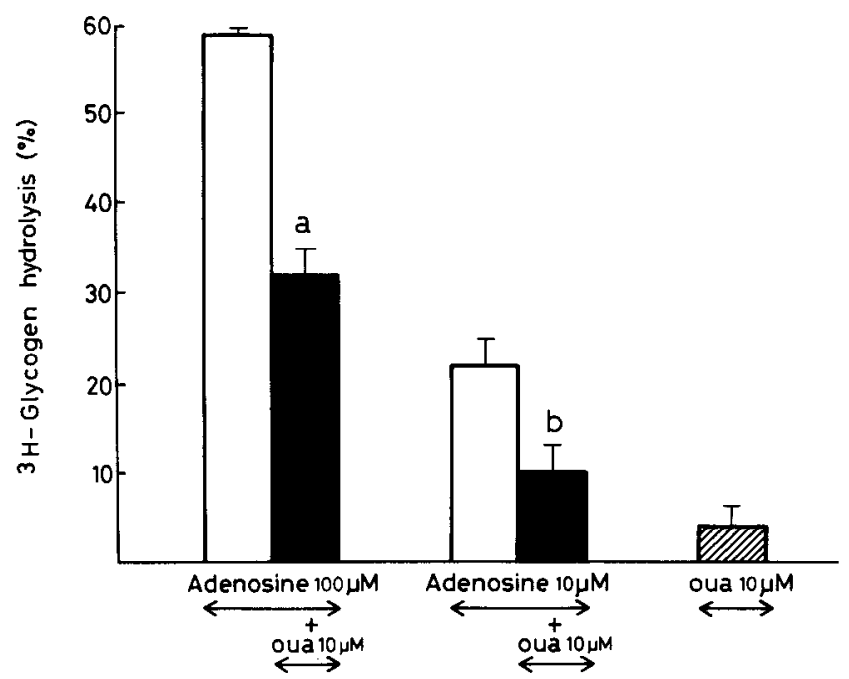

Figure 4. Inhibition by $10 \mu \mathrm{M}$ ouabain of the glycogenolygic effect of 10 and $100 \mu \mathrm{M}$ adenosine. Mouse cerebral cortical slices were incubated as described in Materials and Methods. Results are the means \pm SEM of one experiment ( $n=4$ for each value). Similar results were obtained in 3 separate experiments. Results are expressed as percentages of basal ${ }^{3} \mathrm{H}$-glycogen hydrolyzed. Basal ${ }^{3} \mathrm{H}$-glycogen levels $(\mathrm{cpm} / \mathrm{mg}$ protein): $20,202 \pm 672$. $a$, Significantly different from ${ }^{3} \mathrm{H}$-glycogenolysis observed in the presence of $100 \mu \mathrm{M}$ adenosine alone $(p<0.001) . b$. Significantly different from ${ }^{3} \mathrm{H}-\mathrm{glycogen}$ hydrolysis observed in the presence of 10 $\mu \mathrm{M}$ adenosine alone $(p<0.05)$. SEM of basal levels, $3.32 \%$.
1978; Phillis and Barraco, 1985; Phillis et al., 1979). Furthermore, the alkylxanthines antagonize both the inhibitory and stimulatory effects of adenosine on cAMP generation (Daly et al., 1981; Smellie et al., 1979b), and theophylline competes $\left(\mathrm{IC}_{50}\right.$ in the low micromolar range) with ${ }^{3} \mathrm{H}$-ligands that specifically label adenosine receptors (Bruns et al., 1980). Thus, the observation reported here, that the glycogenolytic action of adenosine is antagonized by theophylline, indicates that adenosine stimulates glycogenolysis through an interaction with specific receptors located on the extracellular surface of target cells.

The rank-order of potencies of adenosine agonists, i.e., ACC > $2 \mathrm{C} 1 \mathrm{~A} \gg \mathrm{CHA}=$ adenosine, the reduced stereospecificity for PIA isomers, and the activity of adenosine at micromolar concentrations represent indications that adenosine promotes glycogenolysis in mouse cerebral cortex through occupation of receptors of the $A_{2}$ type (Daly et al., 1981; Snyder, 1985).

The inhibition of the glycogenolytic action of adenosine by ouabain raises several points for discussion. A first hypothesis to explain this observation is that ouabain antagonizes the stimulatory effect of adenosine on cAMP formation; the cyclic nucleotide's levels would therefore not increase after the occupation of adenosine $A_{2}$ receptors, hence preventing the activation of cAMP-dependent phosphorylation cascades. One of these cAMP-dependent phosphorylation cascades leads to the conversion of the glycogen-hydrolyzing enzyme phosphorylase from its $b$ (less active) to its $a$ form (Siesjö, 1978). However, the interaction observed between ouabain and adenosine on cAMP levels is of an additive (or more than additive) nature, rather than of an inhibitory one (Shimizu and Daly, 1972, and Table 1). This first hypothesis appears therefore unlikely.

A second possibility is that ouabain, by inhibiting the activity of $\mathrm{Na}^{+} / \mathrm{K}^{+}$-ATPase and hence modifying ionic gradients across the cell membrane, inhibits the activation of cAMP-dependent enzymes distal to cAMP formation, thus preventing the expression of the glycogenolytic action of adenosine. This mechanism is supported by the observation indicating that ouabain inhibits hormone-stimulated glycogenolysis in adipocytes (Ho and Jeanrenaud, 1967). Furthermore, in the presence of ouabain or in $\mathrm{K}^{+}$-free media, glycogen synthesis is stimulated in adipocytes (Ho and Jeanrenaud, 1967) and in skeletal muscle (Clausen, 1966). The observation that ouabain antagonizes the glycogenolytic action of VIP and NE (Table 2) further supports the notion of a general inhibitory effect of the cardiac glycoside on the enzymatic process that leads to the breakdown of glycogen. 
Table 1. Stimulatory effect of adenosine, ouabain, and adenosine plus ouabain on cAMP levels in mouse cerebral cortical slices

\begin{tabular}{lcc} 
Agent(s) added & $\begin{array}{l}\text { Conccn- } \\
\text { tration } \\
(\mu \mathrm{M})\end{array}$ & $\begin{array}{l}\text { cAMP } \\
(\mathrm{pmol} / \mathrm{mg} \text { protein) }\end{array}$ \\
\hline None & - & $8.11 \pm 0.91$ \\
Adenosine & 100 & $210.9 \pm 18.7^{a}$ \\
Ouabain & 100 & $145.7 \pm 11.1^{a}$ \\
Adenosine & 100 & \\
$\quad+$ ouabain & 100 & $825.37 \pm 36.3^{b}$
\end{tabular}

$\overline{\text { Experimental conditions as in Figures 1-4, described in detail in Materials and }}$ Methods. Results arc the means \pm SEM of 8 separate determinations.

${ }^{a}$ Significantly different from cAMP levels observed in the absence of added agents, $(p<0.001)$.

"Significantly different from cAMP levels observed in the presence of adenosine, $100 \mu \mathrm{M}$, or ouabain, $100 \mu \mathrm{M}$, tested alone $(p<0.001)$.

It is also conceivable that adenosine could activate a ouabainsensitive, energy-consuming cellular process such as a $\mathrm{Na}^{+} / \mathrm{K}^{+}$ATPase; this would in turn stimulate the mobilization of glycosyl units from glycogen by causing a decrease in the energy charge of the cell (Siesjö, 1978). However, this view seems unlikely, since no evidence exists for a direct activation of $\mathrm{Na}^{+}$/ $\mathrm{K}^{+}$-ATPase by adenosine.

It is worth noting here that adenosine and ouabain have been shown to display antagonistic interactions on at least 2 other cellular actions. First, adenosine has been shown to antagonize the ouabain-induced release of $\mathrm{ACh}$ from the neuromuscular junction of the frog (Branisteanu et al., 1979). This inhibitory action of adenosine has been proposed to be the consequence of a decrease in intracellular free $\mathrm{Ca}^{2+}$ concentration (Branisteanu et al., 1979). Second, ouabain significantly decreased the efficacy of adenosine in relaxing rabbit coronary and femoral arteries in vitro (Foley, 1984).

In summary, the observations presented in this article would indicate that one of the actions of ouabain in the CNS may be to impair neurotransmitter-mediated mobilization of energy stores.

Two further qucstions can be raised regarding adenosine-mediated glycogenolysis, i.e., when could it become operative and within which cell types? Adenosine has been shown to be released in the extracellular space upon electrically and chemically induced excitation of cerebral cortical slices (Pull and McIlwain, 1972, 1973; Shimizu et al., 1970a). The concentrations reached by adenosine in the extracellular space following such manipulations have been estimated to be between 150 and $400 \mu \mathrm{M}$ (Pull and Mcllwain, 1972). Furthermore, adenosine derivatives are released from dendrites and axon terminals, thus pointing to a neuronal origin of release (Schubert and Kreutzberg, 1975). In addition, direct evidence for a stimulation-dependent release of ${ }^{3} \mathrm{H}$-adenosine from axon terminals in the dentate gyrus in vivo has been described (Schubert et al., 1976). Experiments reported in this article indicate that adenosine promotes glycogenolysis between 1 and $100 \mu \mathrm{M}$ (Fig. 1), i.e., concentrations that are reached in the extracellular space following depolarization of neurons. Regarding the cellular localization of the adenosine-induced glycogenolysis, an indication is offered by experiments in which the effect of adenosine on ${ }^{3} \mathrm{H}$-glycogen levels was examined in primary cultures of astrocytes (Magistretti et al., 1983). In this cell type, $100 \mu \mathrm{M}$ adenosine hydrolyzed over $50 \%$ of the newly synthesized ${ }^{3} \mathrm{H}$-glycogen (Magistretti et al., 1983). This observation, if representative of interactions occurring also in vivo, indicates the existence of a functional interaction between neurons and astrocytes whereby, upon depolarization, neuronally released adenosine would promote
Table 2. Inhibitory effect of ouabain on the glycogenolytic action of VIP and NE

\begin{tabular}{lcc} 
Agent(s) added & $\begin{array}{l}\text { Concentraiton } \\
(\mu \mathrm{M})\end{array}$ & $\begin{array}{l}{ }^{3} \mathrm{H} \text {-glycogen } \\
\text { hydrolysis } \\
(\%)\end{array}$ \\
\hline None & - & $3.9 \pm 1.3$ \\
Ouabain & 10 & $5.7 \pm 1.5^{a}$ \\
VIP & 0.5 & $53.4 \pm 2.7$ \\
VIP & 0.5 & $7.3 \pm 2^{b}$ \\
$\quad+$ ouabain & 10 & $50.6 \pm 2$ \\
NE & 1 & 9 \\
NE & 1 & $9 \pm 2.7^{c}$ \\
$\quad+$ ouabain & 10 &
\end{tabular}

Experimental conditions as in Figures 1-4 and Table 1, described in detail in Materials and Methods. Results are the means \pm SEM of 12-24 determinations from 4 separate experiments and are expressed as percentages of basal ${ }^{3} \mathrm{H}$-glycogen hydrolyzed. Basal ${ }^{3} \mathrm{H}$-glycogen levels (cpm/mg protein): 44,427 \pm 1192 .

a Not significantly different from ${ }^{3} \mathrm{H}$-glycogen hydrolysis in the absence of added agents $(p>0.05)$.

${ }^{h}$ Significantly different from VIP, $0.5 \mu \mathrm{M}$, alone $(p<0.001)$

${ }^{c}$ Significantly different from NE, $1 \mu \mathrm{M}$, alone $(p<0.05)$.

glycogenolysis in astrocytes and mobilize energy reserves for the active neuronal environment.

\section{References}

Branisteanu, D. D., I. D. Haulica, B. Proca, and B. G. Nhue (1979) Adenosine effects upon transmitter release parameters in the $\mathrm{Mg}^{2+}$ paralyzed neuro-muscular junction of frog. Naunyn Schmiedebergs Arch. Pharmacol. 308: 273-279.

Brown, B. L., J. D. M. Albano, R. P. Ekins, A. M. Sgherzi, and W. Tampion (1971) A simple and sensitive saturation assay method for the measurement of adenosine $3^{\prime}: 5^{\prime}$-cyclic monophosphate. Biochem. J. 121: 561-562.

Bruns, R. F., J. W. Daly, and S. H. Snyder (1980) Adenosine receptors in brain membranes. Binding of $\mathrm{N6}$-cyclohexyl $\left[{ }^{3} \mathrm{H}\right]$ adenosine and $1,3-$ diethyl-8- $\left[{ }^{3} \mathrm{H}\right]$ phenylxanthine. Proc. Natl. Acad. Sci. USA 77: 55475551 .

Bruns, R. F., J. W. Daly, and S. H. Snyder (1983) Adenosine receptor binding: Structure-activity analysis generates extremely potent xanthine antagonists. Proc. Natl. Acad. Sci. USA 80: 2077-2080.

Clauscn, T. (1966) The relationship between the transport of glucose and cations across cell membranes in isolated tissues. II. Effects of $\mathrm{K}^{+}$-free medium, ouabain and insulin upon the fate of glucose in rat diaphragm. Biochim. Biophys. Acta 120:361-368.

Daly, J. W. (1985) Adenosine receptors. Adv. Cyclic Nucleotide Protein Phosphorylation Res. 19: 29-46.

Daly, J. W., R. F. Bruns, and S. H. Snyder (1981) Adenosine receptors in the central nervous system: Relationship to the central actions of methylxanthines. Life Sci. 28: 2083-2097.

Foley, D. H. (1984) Diminished arterial smooth muscle response to adenosine during $\mathrm{Na}^{+}-\mathrm{K}^{+}$pump inhibition. Pfluegers Arch. 400: 8895.

Fredholm, B. B., and C. G. A. Persson (1982) Xanthine derivatives as adenosine receptor antagonists. Eur. J. Pharmacol. 81: 673-676.

Ho, R. J., and Jcanrenaud, B. (1967) Insulin-like action of ouabain. I. Effect on carbohydrate metabolism. Biochim. Biophys. Acta 144 . 61-73.

Kuroda, Y. (1978) Physiological roles of adenosine derivatives which are released during neurotransmission in mammalian brain. J. Physiol. (Paris) 74: 463-470.

Lajtha, A. L., H. S. Maker, and D. D. Clarke (1981) Metabolism and transport of carbohydrates and amino acids. In Basic Neurochemistry, G. J. Siegel, R. W. Albers, R. W. Agranoff, and R. Katzman, eds., pp. 329-353, Little, Brown, Boston, MA.

Lowry, O. H., N. J. Rosebrough, A. L. Farr, and R. J. Randall (1951) Protein measurements with the Folin phenol reagent. J. Biol. Chem. 193: $265-275$. 
Magistretti, P. J., and J. H. Morrison (1985) VIP neurons in the neocortex. TINS 8: 7-8.

Magistretti, P. J., J. H. Morrision, W. J. Shoemaker, V. Sapin, and F. E. Bloom (1981) Vasoactive intestinal polypeptide induces glycogenolysis in mouse cortical slices: A possible regulatory mechanism for the local control of energy metabolism. Proc. Natl. Acad. Sci. USA 78: 6535-6539.

Magistretti, P. J., M. Manthorpe, F. E. Bloom, and S. Varon (1983) Functional receptors for vasoactive intestinal polypeptide in cultured astroglia from neonatal rat brain. Regulat. Peptides 6:71-80.

Magistretti, P. J., J. H. Morrision, W. J. Shoemaker, and F. E. Bloom (1984) Morphological and functional correlates of VIP neurons in cerebral cortex. Peptides 5: 213-218.

Morrison, J. H., and P. J. Magistretti (1983) Monoamines and peptides in cerebral cortex. TINS 6: 146-151.

Phillis, J. W., and R. A. Barraco (1985) Adenosine, adenylate cyclase, and transmitter release. Adv. Cyclic Nucleotide Protein Phosphorylation Res. 19: 243-257.

Phillis, J. W., and P. H. Wu (1981) The role of adenosine and its nucleotides in central synaptic transmission. Prog. Neurobiol. 16: 187-239.

Phillis, J. W., J. P. Edstrom, G. K. Kostopoulos, and J. R. Kirkpatrick (1979) Effects of adenosine and adenine nucleotides on synaptic transmission in the cerebral cortex. Can. J. Physiol. Pharmacol. 57: 1289-1312.

Pull, I., and H. McIlwain (1972) Adenine derivatives as neurohumoral agents in the brain. The quantities liberated on excitation of superfused cerebral tissues. Biochem. J. 130:975-981.

Pull, I., and H. Mcllwain (1973) Output of $\left[{ }^{14} \mathrm{C}\right]$ adenine nucleotides and their derivatives from cerebral tissues. Biochem. J. 136: 893901.

Quach, T. T., C. Rose, and J. C. Schwartz (1978) ( $\left.{ }^{3} \mathrm{H}\right)$-glycogen hydrolysis in brain slices: Responses to neurotransmitters and modulation of noradrenaline receptors. J. Neurochem. 30: 1335-1341.

Quach, T. T., A. M. Duchemin, C. Rose, and J. C. Schwartz (1980) ${ }^{3} \mathrm{H}$-glycogen hydrolysis elicited by histamine in mouse brain slices: Selective involvement of $\mathrm{H}_{1}$-receptors. Mol. Pharmacol. 17:301-308

Quach, T. T., C. Rose, A. M. Duchemin, and J. C. Schwartz (1982) Glycogenolysis induced by serotonin in brain: Identification of a new class of receptor. Nature 298: 373-375.

Sattin, A., and T. W. Rall (1970) The effect of adenosine and adenine nucleotides on the cyclic adenosine $3^{\prime}, 5^{\prime}$-phosphate content of guinea pig cerebral cortex slices. Mol. Pharmacol. 6: 13-23.
Schubert, P., and G. W. Kreutzberg (1974) Axonal transport of adenosine and uridine derivatives and transfer to postsynaptic neurons. Brain Res. 76: 526-530.

Schubert, P., and G. W. Kreutzberg (1975) Dendritic and axonal transport of nucleoside derivatives in single motoneurons and release from dendrites. Brain Res. 90: 319-323.

Schubert, P., K. Lee, M. West, S. Deadwyler, and G. Lynch (1976) Stimulation-dependent release of ${ }^{3} \mathrm{H}$-adenosine derivatives from central axon terminals to target neurones. Nature 260: 541-542.

Shimizu, H., and J. W. Daly (1972) Effect of depolarizing agents on accumulation of cyclic adenosine $3^{\prime}, 5^{\prime}$-monophosphate in cerebral cortical slices. Eur. J. Pharmacol. 17: 240-252.

Shimizu, H., C. R. Creveling, and J. Daly (1970a) Stimulated formation of adenosine $3^{\prime}, 5^{\prime}$-cyclic phosphate in cerebral cortex: Synergism between electrical activity and biogenic amines. Proc. Natl. Acad. Sci. USA 65: 1033-1040.

Shimizu, H., C. R. Creveling, and J. W. Daly (1970b) Cyclic adenosine $3^{\prime}, 5^{\prime}$-monophosphate formation in brain slices: Stimulation by batrachotoxin, ouabain, veratridine, and potassium ions. Mol. Pharmacol. 6: 184-188.

Siesjö, B. K. (1978) Brain Energy Metabolism, Wiley, New York

Skou, J. C. (1965) Enzymatic basis for active transport of $\mathrm{Na}^{+}$and $\mathrm{K}^{+}$ across cell membrane. Physiol. Rev. 45: 596-617.

Smellie, F. W., J. W. Daly, T. V. Dunwiddie, and B. J. Hoffer (1979a) The dextro- and levorotatory isomers of $N$-phenylisopropyladenosine: Stereospecific effects on cyclic AMP-formation and evoked synaptic responses in brain slices. Life Sci. 25: 1739-1748.

Smellie, F. W., C. W. Davis, J. W. Daly, and J. N. Wells (1979b) Alkylxanthines: Inhibition of adenosine-elicited accumulation of cyclic AMP in brain slices and of brain phosphodiesterase activity. Life Sci. 24: 2475-2482.

Snyder, S. H. (1985) Adenosine as a neuromodulator. Annu. Rev. Neurosci. 8: 103-124.

Solling, H., and V. Esmann (1975) A sensitive method of glycogen determination in the presence of interfering substances utilizing the filter-paper technique. Anal. Biochem. 68: 664-668.

van Calker, D., M. Müller, and B. Hamprecht (1978) Adenosine inhibits the accumulation of cyclic AMP in cultured brain cells. Nature 276: 839-841.

van Calker, D., M. Müller, and B. Hamprecht (1979) Adenosine regulates via two different types of receptors, the accumulation of cyclic AMP in cultured brain cells. J. Neurochem. 33: 999-1005. 